\title{
PENGARUH KUALITAS PELAYANAN DAN KUALITAS PRODUK TERHADAP KEPUTUSAN PEMBELIAN SEPEDA MOTOR HONDA BEAT PADA PT.TUNAS DWIPA MATRA CABANG PAREPARE
}

\author{
Arham Djauharuddin, Mulyana Machmud, Ulyana Muslimin, Aryuni \\ ${ }^{1}$ Univesitas Muhammmadiyah Parepare \\ ${ }^{2,3,4}$ Sekolah Tinggi Ilmu Ekonomi Amsir Parepare \\ e-mail: $\frac{*^{1} \text { arhambarru777@gmail.com }}{{ }^{3} \text { ulymuslimin25@gmail.com }}, \underline{{ }^{2} \text { mulyanamahmud.pare@gmail.com }}$,
}

\begin{abstract}
Abstrak
Kualitas pelayanan dapat memberikan suatu dorongan yang kuat, pada pelanggan untuk membentuk suatu hubungan yang baik dengan badan usaha. Pelanggan menilai suatu kualitas layanan tidak hanya berdasarkan pada hasil dari suatu layanan tetapi juga harus memperhitungkan proses pemberian layanan tersebut. Kualitas produk adalah salah satu faktor yang menjadi pertimbangan konsumen dalam membeli sebuah produk dan dalam hal ini perusahaan dituntut untuk memberikan kualitas layanan yang mampu mempengaruhi nilai yang lebih, sehingga berbeda dengan kualitas layanan persaing sehingga kualitas pelayanan menjadi salah satu faktor pertimbangan konsumen sebelum membeli produk. Penelitian ini bertujuan untuk mengetahui seberapa besar pengaruh Kualitas Pelayanan dan Kualitas Produk terhadap Keputusan Pembelian sepeda motor Honda beat pada PT. Tunas Dwipa Matra Cabang Parepare. Metode Analisis yang digunakan yaitu metode Analisis Deskriptif dan Metode Analisis Regresi Berganda. Hasil penelitian ini menunjukkan bahwa secara keseluruhan atau bersama sama ada pengaruh antara variabel independen terhadap variabel dependen.
\end{abstract}

Kata kunci : kualitas pelayanan, kualitas produk, keputusan pembelian.

\begin{abstract}
Quality of service can provide a strong impetus for customers to form a good relationship with the business entity. Customers assess a service quality not only based on the results of a service but also must take into account the service delivery process. Product quality is one of the factors that consumers consider in buying a product and in this case the company is required to provide quality service that is able to influence added value, so that it is different from the quality of competitor services so that service quality is one of the factors for consumer consideration before buying a product. This study aims to determine how much influence the quality of service and product quality on purchasing decisions Honda beat motorbikes at PT. Tunas Dwipa Matra, Parepare Branch. The analysis method used is descriptive analysis method and multiple regression analysis method. The results of this study indicate that overall or collectively there is an influence between the independent variables on the dependent variable.
\end{abstract}

Keywords : service quality, product quality, purchase decisions.

\section{PENDAHULUAN}

Pertumbuhan ekonomi dunia merupakan salah satu wacana yang sangat menonjol dalam konteks perekonomian suatu negara. Hal ini memunculkan perdagangan bebas yang membuat dunia seolah tanpa batas. Banyak produsen barang dan jasa dari suatu negara yang bersaing dengan produsen negara lain untuk menarik minat konsumen dalam perdagangan internasional. Dengan jumlah populasi terbesar keempat di dunia, Indonesia merupakan area perdangangan baik dari sektor riil maupun sektor keuangan, baik dari produksi, komsumsi maupun investasi.

Meningkatnya mobilitas masyarakat pada saat ini dan didukung dengan kurang representatifnya transportasi umum di Indonesia membuat industri otomotif mobil maupun sepeda motor berkembang dengan pesat. Pemerintah dianggap tidak mampu untuk memberikan pelayanan transportasi yang baik kepada masyarakat. Hal ini menjadikan masyarakat memiliki keinginan yang tinggi untuk menggunakan kendaraan pribadi baik kendaraan roda dua maupun 
roda empat, hal tersebut menjadi salah satu alasan industri ini menjadi lebih berkembang dan maju.

Adanya kendaraan roda dua memberikan gambaran sepeda motor merupakan transportasi gerak cepat, juga menjadi alat transportasi yang praktis dan terjangkau. Sepeda motor merupakan jenis kendaraan yang biasa dimiliki oleh berbagai kalangan ekonomi, mulai dari kalangan atas, menengah, bahkan kalangan ekonomi bawahpun juga tidak sedikit yang memiliki kendaraan sepeda motor.

Berbagai macam permintaan pelanggan, merupakan harapan untuk mendapatkan simpati serta loyalitas dari calon pelanggannya. Bila konsumen telah memutuskan untuk menjadi pelanggan maka bisa dipastikan mereka akan membeli produk yang diproduksinya pada perusahaan tersebut. Dengan adanya kebutuhan sarana transportasi terutama sepeda motor menjadi peluang bagi para pelaku bisnis sepeda motor Indonesia untuk meningkatkan keuntungan perusahaan melalui berbagai macam strategi, memicu para produsen sepeda motor untuk selalu berinovasi dari segi mutu, model dan teknologi produknya dengan terus mengikuti kemajuan zaman dan juga keinginan dari konsumen untuk dapat meraih penjualan yang maksimal dari tiap perusahaan sepeda motor karena kebutuhan komsumsi dari sepeda motor yang terus meningkat.

Proses pengambilan keputusan pembelian pada setiap orang pada dasarnya sama, namun proses pengambilan keputusan pada setiap orang akan diwarnai oleh ciri kepribadian, usia, pendapatan dan gaya hidupnya. Keputusan pembelian adalah, sebuah pendekatan penyelesaian masalah pada kegiatan manusia untuk membeli suatu barang atau jasa dalam memenuhi keinginan dan kebutuhannya yang terdiri atas pengenalan kebutuhan dan keinginan pencarian informasi, evaluasi terhadap alternatif pembelian, keputusan pembelian, dan tingkah laku setelah pembelian. Keputusan pembelian sangat penting dilakukan oleh perusahaan-perusahaan yang memasarkan produk sepeda motor. Hal tersebut perlu dilakukan agar perusahaan dapat selalu meningkatkan volume penjualanya itu melalui analisa faktor atau atribut apa saja yang menjadi pertimbangan konsumen dalam membeli sepeda motor. Strategi pemasaran yang tepat merupakan salah satu cara untuk mencapai tujuan perusahaan yaitu dengan mengetahui kebutuhan dan keinginan konsumen sehingga tercipta produk yang tepat.

Kualitas pelayanan dapat memberikan suatu dorongan yang kuat, pada pelanggan untuk membentuk suatu hubungan yang baik dengan badan usaha. Pelanggan menilai suatu kualitas layanan tidak hanya berdasarkan pada hasil dari suatu layanan tetapi juga harus memperhitungkan proses pemberian layanan tersebut.

Kualitas produk adalah salah satu faktor menjadi pertimbangan konsumen dalam membeli sebuah produk. Untuk kualitas produk sendiri Honda beat dikenal sebagai motor yang irit, mesin yang handal dan suku cadang yang awet. Dengan kualitas produk yang bagus dan terpercaya, maka produk akan senantiasa tertanam dibenak konsumen, karena konsumen bersedia membayar sejumlah uang untuk membeli produk yang berkualitas Setelah melihat kualitas dari produk yang ditawarkan, maka dengan sendirinya konsumen akan mencoba membandingkan kualitas layanan yang diberikan, dan dalam hal ini perusahaan dituntut untuk memberikan kualitas layanan yang mampu mempengaruhi nilai yang lebih, sehingga berbeda dengan kualitas layanan persaing sehingga kualitas pelayanan menjadi salah satu faktor pertimbangan konsumen sebelum membeli produk. Dengan kualitas layanan yang memuaskan, mendorong konsumen untuk melakukan pembelian produk yang bersangkutan. Jika suatu perusahaan mampu memberikan pelayanan yang baik, secara langsung atau tidak langsung, citra layanannya akan tersebar luas karena kepuasan yang dirasakan pelanggannya akan disampaikan pelanggan yang satu kepelanggan lainnya secara berantai, sehingga dapat menarik pelanggan yang lebih banyak.

Dealer atau showroom adalah salah satu layanan purnajual yang diberikan oleh PT.TUNAS DWIPA MATRA untuk mempermudah konsumen untuk melihat dan mencari informasi produk yang ditawarkan, serta melakukan pembelian. Honda beat baik secara tunai 
Hal. $641-651$

e-ISSN : 2621-4377 \& p-ISSN : 1829-8524

Hbmepage: https//e-jurnal.stiendbel-indonesiaacid/indexphp/akmen

maupun kredit. Honda beat adalah salah satu produk dari PT.Tunas Dwipa Matra yang berlokasi di Jalan Baumassepe Kota Parepare.

Pada tahun 2019 ini yang terhitung dari bulan Januari sampai bulan Desember terjadi penurunan volume penjualan pada PT.Tunas Dwipa Matra. Walaupun pada bulan November mengalami peningkatan, tetapi kembali menurun kembali pada bulan Desember. Berikut adalah laporan penjualan sepeda motor di PT.Tunas Dwipa Matra Cabang Parepare dari bulan Januari sampai Desember 2019.

Penjualan Sepeda Motor
Pada PT.TUNAS DWIPA MATRA CABANG PAREPARE
PeriodeJanuari - Desember 2019
\begin{tabular}{|c|c|}
\hline BULAN & JUMLAH UNIT \\
\hline JANUARI & 67 \\
\hline FEBRUARI & 65 \\
\hline MARET & 77 \\
\hline APRIL & 75 \\
\hline MEI & 86 \\
\hline JUNI & 58 \\
\hline JULI & 78 \\
\hline AGUSTUS & 92 \\
\hline SEPTEMBER & 88 \\
\hline OKTOBER & 89 \\
\hline NOVEMBER & 101 \\
\hline DESEMBER & 97 \\
\hline
\end{tabular}

Dari data penjualan diatas dapat dilihat bahwa volume penjualan sepeda motor di PT.Tunas Dwipa Matra Cabang Parepare selama tahun 2019 ini mengalami penurunan volume penjualan. Walaupun pada bulan November mengalami peningkatan dengan volume penjualan sebanyak 101 unit, akan tetapi volume penjualan kembali menurun pada bulan Desember dengan volume penjualan sebanyak 97 unit.

Penelitian ini bertujuan untuk mengetahui seberapa besar pengaruh Kualitas Pelayanan dan Kualitas Produk terhadap Keputusan Pembelian sepeda motor Honda beat pada PT. Tunas Dwipa Matra Cabang Parepare.

\section{HIPOTESIS}

Berdasarkan rumusan masalah yang telah dikemukakan sebelumnya, maka penulis mengajukan hipotesis yaitu:

1. Diduga bahwa Kualitas Pelayanan dan Kualitas Produk berpengaruh secara parsial terhadap keputusan pembelian sepeda motor Honda beat pada PT.Tunas Dwipa Matra Cabang Parepare.

2. Diduga bahwa Kualitas Pelayanan dan Kualitas Produk berpengaruh secara simultan terhadap keputusan pembelian sepeda Motor Honda beat pada PT.Tunas Dwipa Matra Cabang Parepare.

\section{METODE PENELITIAN}

1. Analisis deskriptif adalah analisis yang digunakan untuk mendeskripsikan dan mempermudah penafsiran. Instrumen yang digunakan dalam analisis ini adalah table. Untuk menghasilkan informasi penelitian yang lebih rasional dan objektif, maka data-data yang terkumpul dianalisis dengan menggunakan teknik analisis dengan bantuan table frekuensi 
Hal. 641 - 651

dengan menggunakan scale likers untuk mendapatkan data mengenai bobot jawaban yang diberikan oleh responden.

2. Analisis Regresi Berganda adalah pada dasarnya adalah studi mengenai ketergantungan variabel dependen (terikat) dengan satu variabel atau lebih variabel independen (variabel bebas).

Jenis data yang digunakan dalam penelitian ini adalah data kualitatif, yaitu data yang diperoleh dari perusahaan berupa data tertulis, seperti data konsumen dan data kuantitatif, yaitu data yang diperoleh dari perusahaan berupa angka-angka yang dapat dihitung seperti total pelanggan/konsumen dan lainnya yang dapat mendukung pembahasan.

Sumber data yang digunakan dalam penelitian ini adalah data primer, yaitu data yang diperoleh dengan mengadakan pengamatan serta wawancara secara langsung dengan pimpinan perusahaan dan karyawan yang ada kaitannya dengan masalah yang akan dibahas dan data sekunder, yaitu data yang diperoleh dengan mengumpulkan dokumen-dokumen serta sumbersumber lainnya pada PT. Tunas Dwipa Matra Cabang Parepare.

Dengan menguraikan karakteristik responden yang menjadi sampel dalam penelitian ini maka akan dapat diketahui sejauh mana karakteristik responden dalam penelitian ini. Oleh karena itulah deskripsi karakteristik responden dalam penelitian ini dapat dikelompokkan menjadi beberapa kelompok yaitu: jenis kelamin, pekerjaan, usia, yang membeli motor merek Honda Beat pada PT. Tunas Dwipa Matra Cabang Parepare. Dalam melakukan penelitian ini ditetapkan sebesar 91 orang pelanggan yang dijadikan sebagai responden. Dimana dari 91 kuesioner yang dibagikan kepada responden maka semua kuesioner telah dikembalikan dan semuanya dapat diolah lebih lanjut.

\section{Uji Validitas}

Uji validitas tujuannya untuk mengetahui apakah ada pertanyaan-pertanyaan pada kuesioner yang harus dibuang atau diganti karena dianggap tidak relevan. Validitas yang digunakan dalam penelitian ini adalah menggunakan uji moment product correlation atau lebih dikenal dengan namapearsoncorrelation. Penelitian ini menggunakan semua sampel sejumlah $(n)=91$, maka besarnya $\mathrm{df}=91-3=88$. Dimana $\mathrm{a}=0,05$ maka diperoleh $\mathrm{r}$ tabel sebesar 0,207. Berikut adalah hasil olah data validitas dengan menggunakan SPSS 21 dibawah ini :

Hasil Pengujian Validitas

\begin{tabular}{|l|l|l|l|l|}
\hline No & \multicolumn{1}{|c|}{ Indikator } & Korelasi & r table & Keterangan \\
& Penilaian Kualitas Pelayanan & & & \\
& Indikator 1 & 0,875 & 0,207 & Valid \\
& Indikator 2 & 0,909 & 0,207 & Valid \\
& Indikator 3 & 0,895 & 0,207 & Valid \\
& Indikator 4 & 0,855 & 0,207 & Va;id \\
& Indikator 5 & 0,807 & 0,207 & Valid \\
& & & & \\
\hline \multirow{4}{*}{ Penilaian Kualitas Produk } & 0,790 & 0,207 & Valid \\
& Indikator 1 & 0,816 & 0,207 & Valid \\
& Indikator 2 & 0,795 & 0,207 & Valid \\
& Indikator 3 & 0,872 & 0,207 & Valid \\
& Indikator 4 & 0,865 & 0,207 & Valid \\
& Indikator 5 & & & \\
& & & & \\
\hline
\end{tabular}


Hal. 641 - 651

e-ISSN : 2621-4377 \& p-ISSN : 1829-8524

Hbmepage: https//e-jurnal.stienobel-indonesiaacid/indexphp/akmen

\begin{tabular}{|l|l|l|l|l|}
\hline No & \multicolumn{1}{|c|}{ Indikator } & Korelasi & r table & Keterangan \\
\hline \multirow{2}{*}{} & Penilaian Keputusan Pembelian & & & \\
& Indikator 1 & 0,834 & 0,207 & Valid \\
& Indikator 2 & 0,732 & 0,207 & Va;id \\
& Indikator 3 & 0,817 & 0,207 & Valid \\
& Indikator 4 & 0,839 & 0,207 & Valid \\
& Indikator 5 & 0,779 & 0,207 & Valid \\
\hline
\end{tabular}

Sumber : Analisis Validasi

Tabel diatas menunjukkan bahwa semua indikator yang digunakan untuk mengukur variabel-variabel yang digunakan dalam penelitian ini yaitu variabel Kualitas Pelayanan, Kualitas Produk, dan Keputusan Pembelian mempunyai nilai kolerasi 0,207 sehingga hasil tersebut menunjukkan bahwa semua indikator tersebut adalah valid.

\section{Uji Realibilitas}

Pengujian realibilitas dalam penelitian ini menggunakan rumus CronbachAlpha. Hasil pengujian realibilitas dari program SPSS 21 untuk masing-masing variabel yang diringkas pada tabel berikut ini:

Hasil Pengujian realibilitas

\begin{tabular}{|c|c|c|}
\hline Variabel & Alpha & Keterangan \\
\hline Kualitas Pelayanan & 0,918 & Reliabel \\
\hline Kualitas Produk & 0,884 & Reliabel \\
\hline Keputusan Pembelian & 0,853 & Reliabel \\
\hline
\end{tabular}

Sumber : Analisis Reliabilitas

Hasil uji reliabilitas tersebut menunjukkan bahwa semua variabel-varibel mempunyai koefisien Alpha yang 0,5 yaitu variabel penilaian Kualitas Pelayanan sebesar 0,918, variabel Kualitas Produk sebesar 0,884, dan variabel Keputusan Pembelian sebesar 0,853, sehingga dapat dikatakan bahwa seluruh pengukur masing-masing variabel dari kuesioner adalah reliabel. Uji Hipotesis

Setelah dilakukan pengumpulan data yang telah diberikan ke responden dan mendistribusikannya kedalam skor nilai yang sudah di tentukan, langkah selanjutnya yaitu melakukan analisis data dengan menggunakan analisis regresi linear berganda.Analisis ini digunakan untuk mengetahui seberapa besar pengaruh variabel bebas (Kualitas Pelayanan dan Kualitas Produk) terhadap variabel terikat (Keputusan Pembelian).

Untuk lebih mempermudah mengetahui pengaruh variabel independen (Kualitas Pelayanan serta Kualitas Produk) terhadap pengaruh variabel dependen (Keputusan Pembelian), penulis menggunakan bantuan SPSS (Statistic for Products and Service Solution) versi21. Adapun hasilnya adalah sebagai berikut : 
Hal. 641 - 651

\section{Hasil Uji Regresi Linear Berganda}

Coefficients $^{\mathrm{a}}$

\begin{tabular}{|c|c|c|c|c|c|}
\hline \multirow[b]{2}{*}{ Model } & \multicolumn{2}{|c|}{$\begin{array}{l}\text { Unstandardized } \\
\text { Coefficients }\end{array}$} & \multirow{2}{*}{$\begin{array}{c}\text { Standardized } \\
\text { Coefficients } \\
\text { Beta } \\
\end{array}$} & \multirow[b]{2}{*}{$\mathrm{T}$} & \multirow[b]{2}{*}{ Sig. } \\
\hline & B & Std. Error & & & \\
\hline $1 \quad$ (Constant) & 4.624 & 2.078 & & 2.225 & .029 \\
\hline $\begin{array}{l}\text { KUALITAS } \\
\text { PELAYANAN }\end{array}$ & .465 & .085 & .480 & 5.500 & .000 \\
\hline $\begin{array}{l}\text { KUALITAS } \\
\text { PRODUK }\end{array}$ & .332 & .090 & .321 & 3.681 & .000 \\
\hline
\end{tabular}

a. Dependent Variable: KEPUTUSAN PEMBELIAN

Sumber : Data diolah menggunakan SPSS 21

Dalam rumus regresi linear berganda $\mathrm{Y}=\mathrm{a}+\mathrm{b} 1 \mathrm{X} 1+\mathrm{b} 2 \mathrm{X} 2+\mathrm{e}$, dan nilai-nilai output diatas kemudian dimasukkan kedalam persamaan fungsi regresi linear berganda yaitu: $\mathrm{Y}=4,624+0,465 \mathrm{X} 1+0,332 \mathrm{X} 2+\mathrm{e}$

Dari persamaan diatas dapat dijelaskab bahwa:

a. Nilai a (Constanta) = 4,624 artinya, jika Kualitas Pelayanan tidak mengalami perubahan, maka Keputusan Pembelian adalah sebesar 4,624

b. Nilai b1 $=0,465$ artinya, setiap peningkatan Kualitas Pelayanan sebesar 1, maka Keputusan Pembelian meningkat 0,465 dengan asumsi variabel lain bernilai tetap.

c. Nilai b2 $=0,332$ artinya, setiap peningkatan Kualitas Produk sebesar 1, maka Keputusan Pembelian meningkat sebesar 0,332 dengan asumsi variabel lain bernilai tetap.

\section{Uji Simultan (Uji F)}

Uji statistik F pada dasarnya menunjukkan apakah semua variabel independen yang dimasukkan dalam model mempunyai pengaruh secara bersama-sama terhadap variabel dependennya.Hasil perhitungan Uji F ini dapat dilihat pada tabel berikut:

\section{Hasil Uji Simultan (F)}

ANOVA $^{\mathrm{a}}$

\begin{tabular}{|c|c|c|c|c|c|c|}
\hline \multicolumn{2}{|c|}{ Model } & Sum of Squares & Df & Mean Square & $\mathrm{F}$ & Sig. \\
\hline \multirow{3}{*}{1} & Regression & 223.586 & 2 & 111.793 & 40.752 & $.000^{\mathrm{b}}$ \\
\hline & Residual & 241.403 & 88 & 2.743 & & \\
\hline & Total & 464.989 & 90 & & & \\
\hline
\end{tabular}

a. Dependent Variable: KEPUTUSAN PEMBELIAN

b. Predictors: (Constant), KUALITAS PRODUK, KUALITAS PELAYANAN

Sumber : Data diolah dengan menggunakan SPSS 21 
Hal. $641-651$

e-ISSN : 2621-4377 \& p-ISSN : 1829-8524

Hbmepage: https//e-jurnal.stiendbel-indonesiaacid/indexphp/akmen

Dari tabel di atas diperoleh nilai $\mathrm{F}$ hitung sebesar 40,752 > 3,10 dengan nilai sig nifikan 0,000 lebih kecil dari nilai probabilitas 0,05 . Maka ini berarti bahwa variabel Kualitas Pelayanan dan Kualitas Produk berpengaruh signifikasi secara simultan terhadap Keputusan Pembelian motor merek Honda beat pada PT. Tunas Dwipa Matra Cabang Parepare. Dengan demikian dapat dikatakan bahwa Ha diterima dan Ho ditolak.

\section{Uji Parsial (Uji T)}

Uji t digunakan untuk mengetahui apakah variabel-variabel independen (Kualitas Pelayanan dan Kualitas Produk) secara parsial berpengaruh signifikasi atau tidakterhadap variabel dependen (Keputusan Pembelian). Nilai probabilitas 0,05. Apabila nilai signifikasi lebih kecil dari 0,05 maka variabel independen secara parsial berpengaruh signifikan terhadap variabel dependen.

\section{Hasil Uji Parsial (Uji t) \\ Coefficients $^{\mathrm{a}}$}

\begin{tabular}{|c|c|c|c|c|c|}
\hline \multirow[b]{2}{*}{ Model } & \multicolumn{2}{|c|}{$\begin{array}{l}\text { Unstandardized } \\
\text { Coefficients }\end{array}$} & \multirow{2}{*}{$\begin{array}{c}\begin{array}{c}\text { Standardized } \\
\text { Coefficients }\end{array} \\
\text { Beta } \\
\end{array}$} & \multirow[b]{2}{*}{$\mathrm{T}$} & \multirow[b]{2}{*}{ Sig. } \\
\hline & $\mathrm{B}$ & Std. Error & & & \\
\hline 1 (Constant) & 4.624 & 2.078 & & 2.225 & .029 \\
\hline $\begin{array}{l}\text { KUALITAS } \\
\text { PELAYANAN }\end{array}$ & .465 & .085 & .480 & 5.500 & .000 \\
\hline $\begin{array}{l}\text { KUALITAS } \\
\text { PRODUK }\end{array}$ & .332 & .090 & .321 & 3.681 & .000 \\
\hline
\end{tabular}

a. Dependent Variable: KEPUTUSAN PEMBELIAN

Sumber : Data diolah dengan menggunakan SPSS 21

Dari tabel diatas dapat kita simpulkan bahwa variabel Kualitas Pelayanan paling berpengaruh signifikasi terhadap Keputusan Pembelian motor Honda beat pada PT. Tunas Dwipa Matra Cabang Parepare. Hal ini dapat dibuktikan dari nilai t hitung lebih besar dari $\mathrm{t}$ tabel yaitu 5,500>1,987 dan nilai signifikan 0,000 lebih kecil dari nilai probabilitas 0,05. Dengan demikian dapat dikatakan bahwa Ha diterima dan Ho ditolak.

\section{Analisis Koefisien Determinasi (R2)}

Koefisien determinasi ini digunakan untuk menggunakan seberapa besar variabel independen (Kualitas Pelayanan dan Kualitas Produk) memiliki pengaruh terhadap variabel dependen (Keputusan Pembelian) pada PT. Tunas Dwipa Matra Cabang Parepare.

\section{Hasil Koefisien Determinasi $\left(\mathbf{R}^{2}\right)$}

Model Summary

\begin{tabular}{|l|r|r|r|r|}
\hline Model & \multicolumn{1}{|c|}{ R } & R Square & Adjusted R Square & \multicolumn{2}{|c|}{$\begin{array}{c}\text { Std. Error of the } \\
\text { Estimate }\end{array}$} \\
\hline 1 & $.693^{\mathrm{a}}$ & .481 & .469 & 1.656 \\
\hline
\end{tabular}

a. Predictors: (Constant), KUALITAS PRODUK, KUALITAS PELAYANAN

Sumber : Data diolah dengan menggunakan SPSS 21 
Hal. 641 - 651

e-ISSN : 2621-4377 \& p-ISSN : 1829-8524

Hbmepage: https//e-jurnal.stiendbel-indonesiaacid/indexphp/akmen

Berdasarkan tabel diatas dapat disimpulkan bahwa variabel Kualitas Pelayanan dan Kualitas Produk sebesar 0,469 atau (46,9\%) terhadap Keputusan Pembelian motor Honda beat pada PT. Tunas Dwipa Matra Cabang Parepare. Sedangkan sisanya sebesar 0,519 atau $(51,9 \%)$ dipengaruhi oleh faktor-faktor lain yang tidak diteliti oleh peneliti.

\section{HASIL DAN PEMBAHASAN}

Hasil

Deskripsi Data

\section{Karakteristik Responden}

Pada bagian ini akan disajikan gambaran deskripsi data obyek penelitian untuk mendukung analisa kuantitatif dan memberikan gambaran. Dengan menguraikan karakteristik responden yang menjadi sampel dalam penelitian ini maka akan dapat diketahui sejauh mana karakteristik responden dalam penelitian ini. Oleh karena itulah deskripsi karakteristik responden dalam penelitian ini dapat dikelompokkan menjadi beberapa kelompok yaitu: jenis kelamin, pekerjaan, usia, yang membeli motor merek Honda Beat pada PT. Tunas Dwipa Matra Cabang Parepare. Dalam melakukan penelitian ini ditetapkan sebesar 91 orang pelanggan yang dijadikan sebagai responden. Dimana dari 91 kuesioner yang dibagikan kepada responden maka semua kuesioner telah dikembalikan dan semuanya dapat diolah lebih lanjut. Oleh karena itulah akan disajikan deskripsi identitas responden yang dapat diuraikan sebagai berikut:

\begin{tabular}{|c|c|c|c|}
\multicolumn{3}{|c|}{ Karakteristik Responden Berdasarkan Jenis Kelamin } \\
\hline \multirow{3}{*}{ No } & \multirow{2}{*}{ Jenis Kelamin } & \multicolumn{2}{|c|}{ Tanggapan Responden } \\
\cline { 3 - 4 } & & Orang & Persentase(\%) \\
\cline { 3 - 4 } & & 62 & $75 \%$ \\
\hline 1 & Laki-laki & 29 & $25 \%$ \\
\hline 2 & Perempuan & 91 & $100 \%$ \\
\hline \multicolumn{3}{|c|}{ Jumlah } &
\end{tabular}

Sumber : Data Pelanggan PT. Tunas Dwipa Matra Cabang Parepare

Dari tabel diatas, karakteristik responden berdasarkan jenis kelamin, maka dari 91 orang responden yang menjadi sampel dalam penelitian ini. Berdasarkan kelompok jenis kelamin yakni laki-laki sebesar 62 orang atau 75\% dan perempuan 29 orang atau \% pembeli motor Honda beat. Dari data diatas dapat disimpulkan bahwa pembeli motor jenis Honda Beat pada PT. Tunas Dwipa Matra Cabang Parepare didominasi oleh pembeli laki-laki.

\section{Karakteristik Responden Berdasarkan Pekerjaan}

\begin{tabular}{|c|c|c|c|}
\hline \multirow{2}{*}{ No } & \multirow{2}{*}{ Pekerjaan } & \multicolumn{2}{|c|}{ Tanggapan Responden } \\
\cline { 3 - 4 } & & Orang & Persentase(\%) \\
\hline 1 & Pegawai Negeri & 20 & $17 \%$ \\
\hline 2 & Pegawai Swasta & 24 & $23 \%$ \\
\hline 3 & Wiraswasta & 47 & $60 \%$ \\
\hline & Jumlah & 91 & $100 \%$ \\
\hline
\end{tabular}

Sumber : Data Pelanggan PT. Tunas Dwipa Matra Cabang Parepare 
Dari tabel diatas, nampak bahwa dari 91 orang responden pembeli motor Honda beat, di dominasi oleh Pegawai Negeri sebanyak 20 orang atau 17\% dan disusul oleh Pegawai Swasta sebanyak 24 orang atau $23 \%$ dari jumlah keseluruhan responden serta pembeli motor Honda Beat 47 orang atau $60 \%$ dari orang yang berpropesi sebagai wiraswasta.

\begin{tabular}{|c|c|c|c|}
\hline \multirow{2}{*}{ No } & & \multicolumn{2}{|c|}{ Karakteristik Responden Berdasarkan Usia } \\
& \multirow{2}{*}{ Usia } & \multicolumn{2}{c|}{ Tanggapan Responden } \\
\cline { 2 - 4 } & & Orang & Persentase(\%) \\
\hline 1 & $>25$ & 23 & $18 \%$ \\
\hline 2 & $25-35$ & 27 & $20 \%$ \\
\hline 3 & $35-49$ & 31 & $50 \%$ \\
\hline 4 & $>50$ & 10 & $12 \%$ \\
\hline & Jumlah & 91 & $100 \%$ \\
\hline
\end{tabular}

Sumber : Data Pelanggan PT. Tunas Dwipa Matra Cabang Parepare

Dari data diatas,yakni tanggapan responden mengenai usia, maka dari 91 responden yang menjadi sampel dalam penelitian ini didominasi oleh usia antara 35-49 tahun yakni sebesar 31 orang atau 50\%, disusul pembeli dengan umur 25- 35 tahun sebanyak 27 orang atau $20 \%$ dan pembeli dibawah umur 25 tahun sebanyak 23 orang atau $18 \%$, dan dibawah umur 50 tahun sebanyak 10 orang atau $12 \%$. Sehingga dapat disimpulkan bahwa mayoritas pembeli sepeda motor Honda Beat pada PT. Tunas Dwipa Matra adalah orang-orang yang berumur 35-49 tahun.

Karakteristik Responden Berdasarkan Pendidikan

\begin{tabular}{|c|c|c|c|}
\hline \multirow{2}{*}{ No } & \multirow{2}{*}{ Pendidikan } & \multicolumn{2}{|c|}{ Tanggapan Responden } \\
\cline { 3 - 4 } & & Orang & Persentase( \%) \\
\hline 1 & SMU & 58 & $65 \%$ \\
\hline 2 & Perguruan Tinggi & 18 & $20 \%$ \\
\hline 3 & Lain-Lain & 15 & $15 \%$ \\
\hline & Jumlah & 91 & $100 \%$ \\
\hline
\end{tabular}

Sumber : Data Pelanggan PT. Tunas Dwipa Matra Cabang Parepare

Dari tabel diatas, dari 91 responden pembeli motor Honda beat dapat dilihat dari tingkat pendidikan yaitu Perguruan Tinggi 18 orang atau 20\% dan Lain-lain sebanyak 15 orang atau $15 \%$ dari jumlah keseluruhan responden serta pembeli motor Honda beat 58 orang atau $65 \%$ dari orang yang tingkat pendidikan SMU.

\section{Pembahasan}

Kualitas Pelayanan dan Kualitas Produk merupakan bahan pertimbangan konsumen dalam melakukan pembelian motor Honda beat. Kualitas Pelayanan memberikan pengaruh yang besar dan Kualitas Produk memberikan efek terhadap Keputusan Pembelian dalam membeli motor Honda beat, sehingga pada akhirnya menjatuhkan pilihannya pada motor merek Honda beat.

Kualitas Pelayanan secara parsial berpengaruh terhadap Keputusan Pembelian motor Honda beat pada PT. Tunas Dwipa Matra Cabang Parepare. Dimana hasil Uji parsial untuk 

kemudian dengan nilai signifikasi sebesar 0,000 yang berarti $<0,05$. Maka hal pada penelitian ini dinyatakan bahwa Kualitas Pelayanan mempunyai pengaruh terhadap Keputusan Pembelian motor Honda beat pada PT. Tunas Dwipa Matra Cabang Parepare, dimana terbukti kebenarannya maka Ha1 diterima dan Ho1 ditolak.

Kualitas Produk secara parsial berpengaruh terhadap Keputusan Pembelian motor Honda beat pada PT. Tunas Dwipa Matra Cabang Parepare. Dimana hasil Uji parsial untuk variabel Kualitas produk diperoleh $\mathrm{t}=3,681$ lebih besar dari $\mathrm{t}$ tabel $=1,987$ kemudian dengan nilai signifikasi sebesar 0,000 yang berarti $<0,05$. Maka hal pada penelitian ini dinyatakan bahwa Kualitas Produk mempunyai pengaruh terhadap Keputusan Pembelian motor Honda beat pada PT. Tunas Dwipa Matra Cabang Parepare, dimana terbukti kebenarannya maka Ha2 diterima dan Ho1 ditolak.

Kualitas Pelayanan dan Kualitas Produk secara bersama-sama berpengaruh terhadap Keputusan Pembelian. Hal ini dapat dilihat Kualitas Pelayanan dan Kualitas Produk menunjukkan nilai $\mathrm{F}$ hitung $=40,752$ dengan signifikasi sebesar $0,000<0,05$. Maka dalam penelitian ini dapat dinyatakan bahwa Kualitas Pelayanan dan Kualitas Produk mempunyai pengaruh secara bersama-sama dan signifikan terhadap Keputusan Pembelian pada PT. Tunas Dwipa Matra Cabang Parepare.

\section{KESIMPULAN}

1. Kualitas Pelayanan secara parsial berpengaruh terhadap Keputusan Pembelian motor Honda beat pada PT. Tunas Dwipa Matra Cabang Parepare. Dimana hasil Uji parsial untuk v ariabel Kualitas Pelayanan diperoleh $\mathrm{t}=5,500$ jauh lebih besar dari tabel $=$ 1,987, kemudian dengan nilai signifikasi sebesar 0,000 yang berarti $<0,05$. Maka hal pada penelitian ini dinyatakan bahwa Kualitas Pelayanan mempunyai pengaruh terhadap Keputusan Pembelian motor Honda beat pada PT. Tunas Dwipa Matra Cabang Parepare, dimana terbukti kebenarannya maka Hal diterima dan Hol ditolak.

2. Kualitas Produk secara parsial berpengaruh terhadap Keputusan Pembelian motor Honda beat pada PT. Tunas Dwipa Matra Cabang Parepare. Dimana hasil Uji parsial untuk variabel Kualitas produk diperoleh $\mathrm{t}=3,681$ lebih besar dari $\mathrm{t}$ tabel $=1,987$ kemudian dengan nilai signifikasi sebesar 0,000 yang berarti< 0,05. Maka hal pada penelitian ini dinyatakan bahwa Kualitas Produk mempunyai pengaruh terhadap Keputusan Pembelian motor Honda beat pada PT. Tunas Dwipa Matra Cabang Parepare, dimana terbukti kebenarannya maka Ha2 diterima dan Ho1 ditolak.

3. Kualitas Pelayanan dan Kualitas Produk secara bersama-sama berpengaruh terhadap Keputusan Pembelian. Hal ini dapat dilihat Kualitas Pelayanan dan Kualitas Produk menunjukkan nilai $\mathrm{F}$ hitung $=40,752$ dengan signifikasi sebesar $0,000<0,05$. Maka dalam penelitian ini dapat dinyatakan bahwa Kualitas Pelayanan dan Kualitas Produk mempunyai pengaruh secara bersama-sama dan signifikan terhadap Keputusan Pembelian pada PT. Tunas Dwipa Matra Cabang Parepare.

\section{SARAN}

Bagi peneliti selanjutnya yang tertarik untuk melakukan penelitian dengan judul yang sama, sebaiknya melakukan penelitian atau kajian yang lebih mendalam lagi dan kepada penelitian berikutnya disarankan untuk melakukan penelitian yang lebih lanjut dengan menggunakan variabel lain

\section{UCAPAN TERIMA KASIH}

Penulis menyampaikan ucapan terima kasih dan penghargaan yang tulus kepada:

1. Pimpinana dan seluruh karyawan PT. Tunas Dwipa Matra Cabang Parepare, yang telah memberikan izin untuk mengadakan penelitian di Perusahaannya. 
2. Secara khusus penulis ingin mengucapkan terima kasih yang tak terhingga dan setulustulusnya kepada keluarga yang telah memberikan motivasi, bimbingan, doa sehingga penulis mendapat kemudian dalam menyelesaikan penelitian ini.

3. Teman-teman semua yang telah memberikan bantuan, motivasi dan dorongan selama menyelesaikan penelitian ini.

Semoga Tuhan yang Maha Esa senantiasa membalas pengorbanan tulus yang telah diberikan dengan segala limpahan rahmat dan hidayat dari-Nya. Akhir kata semoga Jurnal ini dapat bermanfaat bagi kita semua. Amin.

\section{DAFTAR PUSTAKA}

Amrullah, Pamasang S. Siburian, Saida Zainurossalamia ZA, (2016). Pengaruh kualitas produk dan kualitas layanan terhadap keputusan pembelian sepeda motor Honda Beat. Jurnal Ekonomi dan Manajemen, 13. 2.

Brayen Panget, (2018). Pengaruh kualitas produk terhadap keputusan pembelian sepeda motor Honda Beat pada CV.LION di ternate. Jurnal Administrasi Bisnis, 6. 4.

D.Ph, Tjiptono Fandy dan Diana Anastasia, (2016). Pemasaran Esensi \& aplikasi, Yogyakarta: ANDI.

Edy Gufran Darwis, (2017). Pengaruh brand image dan harga terhadap keputusan pembelian mobil Toyota avanza pada PT. Hadji Kalla Cabang alauddin: Makassar.

Fransiscus Xaverius Febrianto, (2019).Pengaruh harga, kualitas produk, dan pelayanan terhadap keputusan pembelian produk Feysen melalui media sosial, diYogyakarta.

Irna Windu Prasetyani, Handoyo Djoko Waluyo \& Agung Budiatmo, (2017). Pengaruh kualitas pelayanan, Citra merek dan kualitas produk terhadap keputusan pembelian konsumen sepeda motor Honda Beat di PT.Nusantara Sakti Semarang, Semarang.

Mohammad Najmi Mujaddid Dinda shwara, (2016). Pengaruh kualitas pelayanan dan kualitas produk terhadap keputusan pembelian konsumen sepedamotor Honda Beat produksi PT. Astra Honda Motor Jakarta. Jurnal Manajemen, 3. 3.

Meilina Boediono, Sonata Christian, Dewi Mustika sari Immanuel, (2018). Pengaruh kualitas produk dan kualitas layanan terhadap keputusan pembelian konsumen Sealantwax. Jurnal Manajemen dan Start-Up Bisnis, 3. 1.

Ni Kadek Karmiasih, (2018).Pengaruh kualitas pelayanan terhadap keputusan pembelian motor Honda Beat Esppada PT. Daya Anugrah Mandiri Parepare.

Nurjannah Daulay, (2017). Pengaruh kualitas pelayanan dan kualitas produk terhadap keputusan pembelian, Surabaya. 